\title{
The Effect of Dietary Inclusion of Probiotics on Growth and Intestinal Morphology of Broiler Chickens
}

\author{
Murat Gulmez ${ }^{1 * a}$, Nurhayat Gulmez ${ }^{2}$, Seyitali Bingol ${ }^{3}$, Turgay Deprem ${ }^{4}$ and Serap Koral Tasci ${ }^{4}$ \\ ${ }^{1}$ Asilcag Trading Ltd. Nicossia, Cyprus. \\ ${ }^{2}$ Near East University, Faculty of Veterinary Medicine, Department of Histology and Embriology, Nicossia, North Cyprus \\ ${ }^{3}$ Kafkas University, Faculty of Medicine, Department of Histology and Embriology, Kars, Turkey \\ ${ }^{4}$ Kafkas University, Faculty of Veterinary Medicine, Department of Histology and Embriology, Kars, Turkey \\ ${ }^{a}$ Research support provided in part by a grant from the Scientific and Technological Research Council of Turkey, Ankara, Turkey \\ *Corresponding author's Email: mgulmez@hotmail.com; ORCID: 0000-0003-3888-6815
}

Received: 07 Feb. 2019

Accepted: 15 Mar. 2019

\begin{abstract}
Probiotics are currently under investing the most valuable substances alternative to antibiotic growth promoters in poultry breeding practice. This research was performed to evaluate the effect of supplementing broiler drinking water with probiotics (Pediococcus acidilactici and Bacillus subtilis) at a concentration of $\geq 10^{8} \mathrm{CFU} / \mathrm{ml}$ during 42 days of feeding period on growth performance and gut health. A total of 144 one-day-old Ross 308 broiler chicks (mixed gender) with an average initial BW of $42.3 \mathrm{~g}$ were used. The chicks were allotted to pens with 12 birds per pen and six replications per treatment with food and water provided ad libitum. Feed intake of Probiotic group was $4134 \mathrm{~g}$, $338 \mathrm{~g}$ less than that of control group. Live weight of probiotic group was $2537 \mathrm{~g}$ and a $113 \mathrm{~g}$ more than that of control group. The feed conversion ratio of probiotic group was 1.61, 0.22 less than that of control group. The crypt depth of probiotic group $(1110.46 \pm 224.016 \mu \mathrm{m})$ was statistically deeper than that of control group $(949.39 \pm$ $114.166 \mu \mathrm{m}$ ) in ileum. Continuously use of probiotics in drinking water of commercial poultry flocks appears to be alternative to AGPs. The results of this study provide a greater understanding of the impact of long-life use of probiotics on broiler health and growth performances.
\end{abstract}

Key words: Broiler, Gut morphology, Growth performances, Probiotics

\section{INTRODUCTION}

Globally, antibiotic resistance is a growing public health issue (Gaggia et al., 2011). This emerging issue will likely lead to even greater challenges that will requisite innovative solutions in order to provide even greater public health protection. The goal is to enhance the knowledge base of alternative antimicrobials currently under investigation and to identify additional materials for potential strategic use in food animal production, leading to better protection of human health (Hume, 2011).

Antibiotics as growth promoters in animal feeds have been used in the member states of the European Union during the last $50 \mathrm{yr}$. However, the EU banned antimicrobial growth promoters (AGPs) in Jan 2006. So, the poultry industry has aimed to develop new strategies in order to maintain animal health and performance on a commercial scale (Castanon, 2007; Vahdatpour and Babazadeh, 2016). Accordingly, scientific efforts have been focused on the development of new non-antibiotic health and growth promoters for use in poultry breeding
(Griggs and Jacob, 2005; Nikpiran et al., 2014). Such as from AGPs, it is expected from non-AGPs that they should promote digestive tract health to increase disease resistance in chickens (Istiqamah et al., 2013; Mahdavi et al., 2013; Afsharmanesh and Sadaghi,2014; Li et al., 2014 and Chughtai et al., 2015).

As a source of non-AGPs, extracts of some medicinal or aromatic plants, probiotics, prebiotics, Competitive Exclusion (CE) cultures, organic acids, specifically fermented feeds or their extracts has been used (Lee et al., 2001 and Prukner-Radovcic and Grozdonic, 2003). Except for these attempts, intensive efforts have been spent in developing dietary fibers, bacteriocins, strain specific phages and vaccines to combat many significant enteric diseases (Heres et al., 2003; Vandeplas et al., 2008 and Latha et al., 2016).

Probiotics are live microbial complements that provide beneficial effects on the host due to improvement in the intestine's microbial equilibrium (Fuller, 1989 and Giannenas et al., 2014). Sharma et al. (2012) demonstrated 
them as "the emissaries of health from microbial world". The efficacy of these products is often due to specific microbial ecological factors that alter the competitive pressures experienced by the microbial population of the gut (Callaway et al., 2008 and Lutful Kabir, 2009). Many researchers have suggested that probiotics and CE cultures can reduce colonization of pathogenic bacteria in chickens' intestines (Lee et al., 2001; Wolfenden et. al., 2007 and Schneitz et al. 2016).

Feed efficiency, feed conversion ratio, survival rate and weight gain rate are considered as the main parameters for evaluating effectiveness of non-AGPs in scientific studies, either via comparison with AGPs or using them alone (Mehr et al, 2014; Olnood et al., 2015 and Zhang et al., 2015). Gut histopathology, blood and digestive parameters are used as comparison parameters in such studies (Mehr et al, 2014; Agboola, 2015 and Ştef et al., 2015). Varieties of non-AGPs recommended for use in drinking water or in combination with poultry feed (Swiatkievicz, 2014 and Abu Akkada et al., 2015). Many studies have revealed the effectiveness of non-AGPs as growth promoters, providing alternative to AGPs to improve chicken growth indices (Landy and Kavyani, 2013). From the literature, it appears to be difficult to come to a consensus as to the best method to probiotic application for broiler chickens on an industrial scale. So, a liquid probiotic was used (Smart ProLive, a commercial preparation) in non-chlorinated drinking water once a day. So, it is aimed to investigate the effects of on growth performance and some histological changes in large intestines of broiler chicks during a period of $42 \mathrm{~d}$ of breeding.

\section{MATERIALS AND METHODS}

A total of 144 one dayold Ross 308 broiler chicks (mixed sexes) with an average initial BW of $42.3 \mathrm{~g}$ were allotted to pens with 12 birds per $1 \mathrm{~m}^{2}$ cages in a $20 \mathrm{~m}^{2}$ environmentally controlled room (32 to $24{ }^{\circ} \mathrm{C}$ and $65 \%$ relative humidity) flock. Six control (control group) and six experiment (probiotic group) cages were placed on the ground as two parallel lines. Four $\mathrm{kg}$ of wood shavings was used as bedding material for each cage. The light regime was $23 \mathrm{~h}$ light and one $\mathrm{h}$ darkness. The temperature in the flock was $32^{\circ} \mathrm{C}$ at the beginning of the experiment and was gradually reduced to $21^{\circ} \mathrm{C}$ at $21 \mathrm{~d}$. Broiler chickens were vaccinated with live attenuated vaccines against Newcastle Disease Virus (NDV) Avinew@ VG/GA strain (Merial-Lyon-France) at day 7 and day 26. No antimicrobial agent was applied to the birds. Birds were only subjected to 3 routine vaccination applications at different intervals and vaccines were applied to all the birds via drinking water.

The birds were provided with ad libitum feed and drinking water during the entire experimental period. All diets were taken from a commercial Ross 308 broiler chicken breeding farm. Chickens were feed with four structures of compound feed according to the recommendations in the growth boom for Ross 308 hybrid, namely: pre-starter, starter, grower and finisher in the following sub-periods: from hatching to $10 \mathrm{~d}$, from 11 $\mathrm{d}$ to 24 , from 24 to $35 \mathrm{~d}$ and from 36 to $42 \mathrm{~d}$. The feed compositions are given in table 1 . Control group was fed with basal diet and de-chlorinated drinking water. Probiotic group was fed with basal diet and de-chlorinated drinking water with $0.1 \%$ Smart ProLive. Live weight and feed consumption ratio (FCR) were recorded weekly until $42 \mathrm{~d}$ (slaughter d).

Table 1. Composition of basal diets $(\mathrm{g} / \mathrm{kg})$ used for feeding of broiler chickens.

\begin{tabular}{|c|c|c|c|c|}
\hline \multirow{2}{*}{$\begin{array}{l}\text { Composition of basal diets }(\mathrm{g} / \mathrm{kg}) \\
\text { Ingredients }\end{array}$} & \multicolumn{4}{|c|}{ Feeding periods (day) } \\
\hline & 0-10 & 11-24 & $25-35$ & $36-42$ \\
\hline Maize & 440 & 392.22 & 361.55 & 357.42 \\
\hline Soybean Meal (46\%) & 210 & 84 & 21 & 0 \\
\hline Soybean (Full fat) & 150 & 200 & 270 & 267 \\
\hline Wheat & 85.6 & 197 & 247 & 267 \\
\hline Maize gluten & 54.5 & 24 & 0 & 0 \\
\hline Limestone & 16.6 & 9.4 & 8.6 & 8.4 \\
\hline Soybean oil & 15 & 5 & 5 & 3 \\
\hline $\mathrm{CaHPO}_{4}$ & 12.3 & 5.1 & 3.6 & 3.7 \\
\hline L-Lysine $\mathrm{HCl}$ & 4.1 & 3.89 & 2.58 & 2.76 \\
\hline DL-Methionine & 2.94 & 2.67 & 2.35 & 2.18 \\
\hline $\mathrm{NaHCO}_{3}$ & 2.44 & 3.4 & 3.14 & 3.85 \\
\hline $\mathrm{NaCl}$ & 2.16 & 1 & 1.2 & 0.62 \\
\hline L-Threonine & 1.13 & 0.78 & 0.78 & 0.85 \\
\hline Meat-bone meal & 0 & 60 & 60 & 70 \\
\hline Vegetable oil & 0 & 5 & 10 & 10 \\
\hline Vitamin premix ${ }^{\text {a }}$ & 0.2 & 0.2 & 0.2 & 0.2 \\
\hline Mineral premix ${ }^{b}$ & 2 & 2 & 2 & 2 \\
\hline Choline chloride & 1 & 1 & 1 & 1 \\
\hline \multicolumn{5}{|l|}{ Nutrient level } \\
\hline Metabolizable energy $(\mathrm{MJ} / \mathrm{kg})^{\mathrm{c}}$ & 3037 & 3140 & 3225 & 3220 \\
\hline Crude protein $(\%)$ & 23.56 & 20.9 & 19.2 & 18.9 \\
\hline Lysine (g/kg) & 1.45 & 1.3 & 1.15 & 1.13 \\
\hline Methionine $(\mathrm{g} / \mathrm{kg})$ & 0.7 & 0.61 & 0.53 & 0.5 \\
\hline Calcium (g/kg) & 1.25 & 0.96 & 0.92 & 0.95 \\
\hline Available phosphorus (g/kg) & 0.68 & 0.67 & 0.64 & 0.65 \\
\hline \multicolumn{5}{|c|}{$\begin{array}{l}\text { a Vitamin premix provided } 1 \mathrm{~kg} \text { of diet with: vitamin } \mathrm{A}, 10.800 \mathrm{IU} \text {; } \\
\text { vitamin D3. } 2160 \mathrm{IU} \text {; vitamin } \mathrm{E}, 15 \mathrm{IU} \text {; Vitamin } \mathrm{K} 3,1.0 \mathrm{mg} \text {; vitamin } \mathrm{B} 1 \text {, } \\
4 \mathrm{mg} \text {; riboflavin, } 5 \mathrm{mg} \text {; pantothenic acid, } 10 \mathrm{mg} \text {; niacin } 25 \mathrm{mg} \text {; vitamin } \\
\mathrm{B} 6,8 \mathrm{mg} \text {; folic acid, } 0,4 \mathrm{mg} \text {; vitamin } \mathrm{B} 12,0.08 \mathrm{mg} \text {; biotin, } 0,15 \mathrm{mg} .{ }^{\mathrm{b}} \\
\text { Mineral premix provided } 1 \mathrm{~kg} \text { of diet with: I, } 0,35 \mathrm{mg} \text {; Se, } 0,15 \mathrm{mg} \text {; Zn, } \\
40 \mathrm{mg} \text {; } \mathrm{Cu}, 8 \mathrm{mg} \text {; Fe, } 80 \mathrm{mg} \text {; Mn, } 100 \mathrm{mg} \text {. 'Metabolizable energy was } \\
\text { obtained by calculation. }\end{array}$} \\
\hline
\end{tabular}


Enumeration of total aerobic bacteria in the probiotic source: Smart ProLive sold in the form of 51 plastic container (as seen on the label, it contains $\geq 1 \times 10^{11}$ $\mathrm{CFU} / \mathrm{ml}$ probiotics as Pediococcus acidilactici and Bacillus subtilis) was analyzed for its total viable bacterial count. A $10 \mathrm{ml}$ sample was mixed with $90 \mathrm{ml}$ sterile saline solution $(0.9 \% \mathrm{NaCl})$ and the10-fold increment serial dilution technique was conducted according to Maturin and Peele (2001). One milliliter of the homogenized suspension was then transferred into $9 \mathrm{~mL}$ of $0.9 \%$ saline solution $(\mathrm{NaCl})$ and serially diluted from $10^{-1}$ to $10^{-8}$ by using the same saline solution tubes. From the last three diluted samples, $0.1 \mathrm{~mL}$ each was plated on the appropriate agar medium for enumeration of live bacterial population. After colony count, bacterial load was calculated as $\mathrm{CFU} / \mathrm{ml}$.

\section{Histological measurements}

At the $42^{\text {th }} \mathrm{d}$ of the trial period, all the birds were weighed individually and sent to a local commercial broiler slaughterhouse for the routine slaughter process. Electrically stunned birds were slaughtered. For histological examination, fragments from duodenum, ileum and ceca were taken from the individuals of six experimental variants in each of Probiotic Group and Control Group after the commercial slaughtering process. The fragments of the intestine were fixed in neutral formalin (10\%), then dehydrated in increasing ethylic alcohol solutions $\left(70^{\circ}, 80^{\circ}, 90^{\circ}, 100^{\circ}\right)$ and clarified in two baths of benzene and put in paraffin. The sectioning of the paraffin blocks was carried out using a manually rotary microtome (Ştef et al., 2015). The slides were stained with Periodic Acid Schiff (PAS) and Hematoxylin Eosin (HE) then examined by light microscopy. Micrometer in microscope was used for histometric measurements (Luna, 1968).

\section{Statistical analysis}

Data were analyzed using SPSS v.16.0 for Windows (SPSS Inc., Chicago, IL, USA). Statistically significant differences between group means were determined by independent sample $t$ test. Mean values were considered significantly different at $\mathrm{P}<0.05$. Data are expressed as mean values $\pm \mathrm{SD}$ (standard deviation).

\section{Ethical approval}

Direct collection of tissues and organs from freshly slaughtered birds was carried out in strict accordance with the recommendations of Kafkas University, Kars, Turkey for the care and use of laboratory animals. Also, slaughtered chickens were humanly handled.

\section{RESULTS}

There was no mortality or physical injury during the trial period of $42 \mathrm{~d}$. After a $42 \mathrm{~d}$ of breeding period, each bird in probiotic group consumed $4134 \pm 112 \mathrm{~g}$ feed and it was $338 \mathrm{~g}$ less than that of control group $(4472 \pm 137 \mathrm{~g})$. Live weight of each bird in the probiotic group was $2537 \pm 62 \mathrm{~g}$ and it was $113 \mathrm{~g}$ more than that of Control Group $\left(2424 \pm 67 \mathrm{~g}\right.$ at $\left.42^{\text {nd }} \mathrm{d}\right)$. The FCR of probiotic group was $1.61 \pm 0.007$ and it was 0.22 less than that of control group $(1.83 \pm 0.012)$. As seen in the table 2, feed consumption, weight gain and FCR results of probiotic group were superior to that of control group during all the breeding period. After total mesophilic aerobic count of the probiotic source, it is confirmed that it contained at the concentration of $1 \times 10^{11} \mathrm{CFU} / \mathrm{ml}$ (data has not been shown).

The figures 1 and 2 represent the guts histological structures. There was no difference between probiotic group and control group aspect of histological structure, which were lymph follicles, goblet cells, crypt, submucosa and mucosa, in all parts of small intestine. The histometric differences between the two groups are given in table 3 . Although the crypt depth in duodenum and in ceca of probiotic group and control group were statistically similar to each other, there was a significant difference between the two groups in ileum. The crypt depth of probiotic group $(1110.46 \pm 224.016 \mu \mathrm{m})$ was statistically deeper than that of control group $(949.39 \pm 114.166 \mu \mathrm{m})$ in ileum. Mucosa thickness of probiotic group in ceca and ileum appeared to be thicker than those of control group in those parts of the intestine (Table 3). There was no statistically significant difference between the two groups in the thickness of the duodenum mucosa (Table 3).

Table 2. Effect of probiotic (Smart ProLive) on growth parameters during 42 days of rearing period of broiler chickens (mean \pm SE).

\begin{tabular}{lcccccc}
\hline Tests & $\mathbf{1}$ & $\mathbf{2}$ & $\mathbf{3}$ & $\mathbf{4}$ & $\mathbf{5}$ & $\mathbf{6}$ \\
\hline Feed intake; & 89 & 407 & 930 & 1734 & 2270 & 4134 \\
Probiotic & \pm 6 & \pm 14 & \pm 22 & \pm 40 & $\pm 75^{*}$ & $\pm 112^{*}$ \\
\hline Feed intake; & 89 & 396 & 954 & 1780 & 2979 & 4472 \\
Control & \pm 6 & \pm 24 & \pm 30 & \pm 72 & \pm 76 & \pm 137 \\
\hline Bodyweight gain; & 121 & 369 & 722 & 1235 & 1879 & 2537 \\
Probiotic & \pm 6 & \pm 12 & \pm 15 & $\pm 27 *$ & $\pm 47 *$ & $\pm 62^{*}$ \\
\hline Bodyweight gain; & 112 & 338 & 689 & 1175 & 1796 & 2424 \\
Control & \pm 6 & \pm 18 & \pm 21 & \pm 45 & \pm 47 & \pm 67 \\
\hline Feed conversion & 0.39 & 0.99 & 1.23 & 1.37 & 1.45 & 1.61 \\
rate; Probiotic & \pm 0.03 & \pm 0.08 & \pm 0.06 & $\pm 0.04 *$ & $\pm 0.04 *$ & $\pm 0.07 *$ \\
\hline Feed conversion & 0.42 & 1.05 & 1.32 & 1.48 & 1.64 & 1.83 \\
rate; Control & \pm 0.01 & \pm 0.02 & 0.05 & 0.05 & 0.01 & 0.01 \\
\hline$*$ P $<0.05$. & & & & & &
\end{tabular}



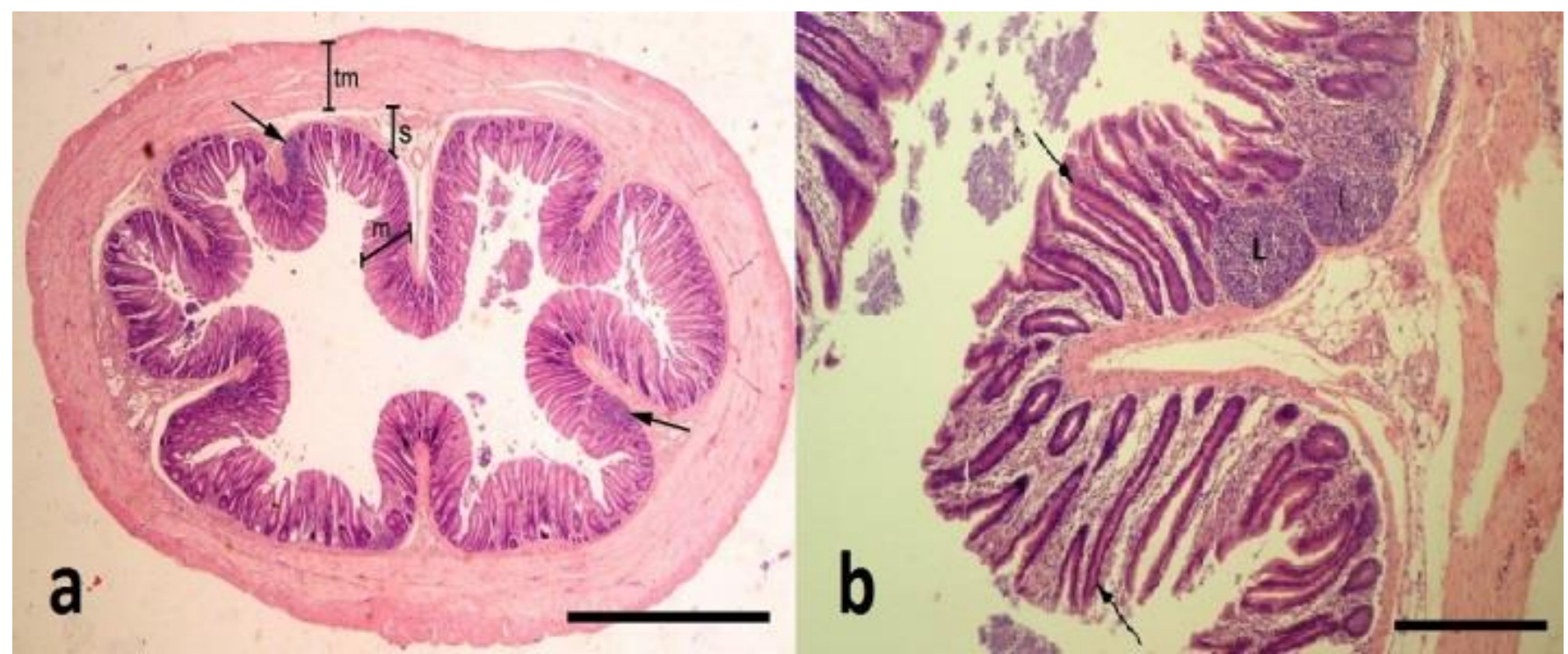

Figure 1. a) General view of the cecum in the experimental group of broiler chickens after 42 days of rearing period, 4x.Arrows: Lymph follicles, tm: tunica muscularis, s: submucosa, m: mucosa. Haematoxylin and eosin stain (H\&E) Bar: 1000 $\mu \mathrm{m}$; b) Cecum of the experimental group, 10x. Arrows: Crypt, L: lymph follicles. H\&E. Bar: $200 \mu \mathrm{m}$.

Table 3. Effect of probiotic on crypt depth and mucosa thickness in gut segments of broiler chickens after 42 days of rearing period.

\begin{tabular}{|c|c|c|c|c|c|}
\hline Tissue & Groups & Crypt depth $(\mu \mathrm{m}) \pm \mathrm{SD}$ & $\mathbf{F}$ & Mucosa thicknes $(\mu \mathrm{m}) \pm \mathrm{SD}$ & $\mathbf{F}$ \\
\hline \multirow{2}{*}{ Doudenum } & Probiotic & $1622.5 \pm 347.0$ & \multirow{2}{*}{0.666} & $1965.1 \pm 333.4$ & \multirow{2}{*}{0.37} \\
\hline & Control & $1445.7 \pm 318.7$ & & $1721.6 \pm 326.3$ & \\
\hline \multirow{2}{*}{ Ileum } & Probiotic & $1110.5 \pm 224.0$ & \multirow{2}{*}{$9.305^{*}$} & $1325.2 \pm 222.8$ & \multirow{2}{*}{$8.78^{*}$} \\
\hline & Control & $949.39 \pm 114.2$ & & $1144.9 \pm 129.0$ & \\
\hline \multirow{2}{*}{ Ceca } & Probiotic & $306.8 \pm 65.1$ & \multirow{2}{*}{0.275} & $402.8 \pm 109.5$ & \multirow{2}{*}{$4.73 *$} \\
\hline & Control & $273.8 \pm 59.3$ & & $353.1 \pm 63.1$ & \\
\hline
\end{tabular}

*P $<0,05$.

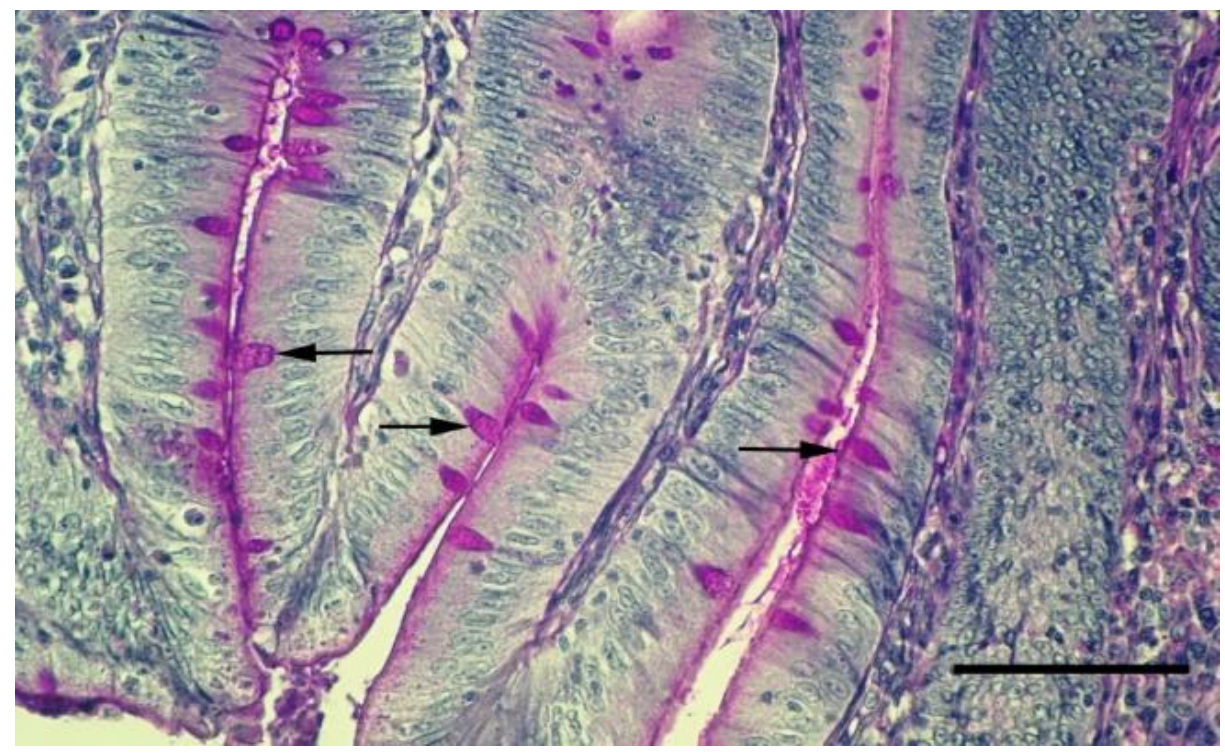

Figure 2. Duodenum of the experimental group of broiler chickens after 42 days of rearing period. Arrows: Goblet cells, 40x. Periodic Acid Schiff (PAS). Bar: $50 \mu \mathrm{m}$. 


\section{DISCUSSION}

Antibiotics used in the field of veterinary application have been found to be responsible for the global antibiotic resistance problem. Currently, there is an alarming situation regarding antimicrobial resistance (Tellez et al., 2012). In 2013, the G8 summit was dedicated this subject alone and at the end of the summit the conclusion was that the situation had demonstrated as "an alarm state". The G8 ministers released a joint statement on June 14, identifying antimicrobial drug resistance as a "major health security challenge of the 21st century" (Davies, 2013).

Competition of good and bad flora demonstrates the health of the digestive system, and accordingly health of the total body (Ghadban, 2002). AGPs are used to suppress bad flora and allowing good flora to dominate in the intestines. Ban of antibiotic growth promoters in feeds from 2006 in the EU countries, many other countries have gradually adapted their regulations. After the ban, a rapid search has started to find new growth promoters to replace AGPs (Hume, 2011). In last 20 years, many studies have been conducted on new natural gut health promoters such as probiotics, prebiotics, CE cultures, direct feed microbials, fermented feeds, organic acids, essential oils. Probiotic are defined as a live microbial feed supplement that beneficially affects the host animal by improving its microbial intestinal balance (Fuller, 1989). Given the lack and hazards of antibiotics, including reduction of microbiome diversity and antibiotic resistance, the use of probiotics instead of antibiotics is becoming increasingly more acceptable. (Nami et al., 2015). Probiotics, prebiotics and $\mathrm{CE}$ cultures have demonstrated to be the good natural digestive system promoters (Ghadban, 2002 and Nami et al., 2015). It is also pointed out by this study that probiotics can be used in broiler meat production as gut health enhancer and growth promoter.

Many studies have been conducted to determine, the efficacy of non-AGPs on the health and growth performances of meat chickens. Nevertheless, it is not easy to make a comparative evaluation on the subject (Applegate et al., 2010). Due to differences in breeding conditions, feed and water quality, and probiotic and CE culture type, confirmative results between scientific studies has not easily been demonstrated (Otutumi et al., 2012). Variations in the effects of probiotics on growth performance of broiler chickens may be attributed to differences in the strains of bacteria used as dietary supplements (Angel et al., 2005; Timmerman et al., 2006; O’Dea et al., 2006; Lutful Kabir, 2009; Blajman et al.,
2015 and Olnood et al., 2015). Differences between physical and environmental conditions of the trials may also bias the results from these studies (Olnood et al., 2015). Also, an accurate dosage of administration has not yet to be established despite the wide use of probiotics (Khan et al. 2013; Li et al., 2014; Abu-Akkada and Awad, 2015 and Getachew, 2016). A continuously giving the probiotics via drinking water to the broiler chicken at whole breeding period may be more trusted way for taking maximum profit from it.

Adding to feed is the most commonly used method for administering probiotic preparations to broiler chickens in poultry production. Nevertheless, feed-type probiotic products rarely produce optimum results in pelletized diets usually fed to broilers (MacDonald and Wang, 2011). Probiotic bacteria incorporated into crumbles have an increased lifespan than those in pelletized feed (Eckert et al., 2010). Only spore forming probiotic bacteria can successfully survive in pelletized feed. Thus, the best natural solution to challenge the stability non-spore forming probiotic bacteria may be used in drinking water. However, chlorinated water can decline viability of the organisms rapidly (Raevouri et al., 1978). It is also in agreement with the researchers who mentioned that the best way of the giving non-spore forming probiotics to the broiler chickens may be the rote of drinking water.

Nurmi and Rantala (1973) have demonstrated that intubation in to the crop is probably the most satisfactory method for delivering a gap precise dose of probiotics to the animal. However, this route is not an applicable way on an industrial scale. Blankenship (1992) suggested that spray application of probiotic cultures, either on the environment of the birds or on the litter material seems to be an effective way of administering probiotic cultures. This way can also be applied during the first $d$ of life of the chickens in industrial production practices, and it appears not to be easy and practical to apply at the farm level during rearing period.

The results of researches available in literature involving probiotics are very variable, several factors can interfere with the results, such as the type of probiotic, its action mode, its interaction with the host and breeding environment. There are few studies that demonstrate the usefulness of probiotics or $\mathrm{CE}$ cultures on growth performances (Ştef et al., 2015; Abu- Akkada and Awad, 2015 and Getachew, 2016). Almost all of the other studies have demonstrated at least one positive effect including growth promotion of probiotics on the broilers (Mehr et al., 2014; Ritzi et al., 2014; Agboola et al., 2015; Zhang et 
al., 2015; Schneitz et al., 2016 and Erdogmuş et al., 2018). In this study, probiotic use had less feed consumption (338 $\mathrm{g})$, more weight gain $(113 \mathrm{~g})$ and less FCR $(0.22)$ than Control group (Table 2). The results have demonstrated that an efficient result of continuous use of a fresh liquid probiotic source at appropriate dose via drinking water appears to be alternative to AGPs. The performance results were significantly affected by probiotic use.

The Figures 1 and 2 represent the gut morphological structures. No differences were determined or superiority between the groups when examined the duodenum samples. There was no difference between probiotic group and control group aspect of histological structure, which were lymph follicles, goblet cells, crypt, submucosa and mucosa, in duodenum. The histometric differences between the two groups are given in table 3 . There was no statistical significance in the crypt depth of duodenum and ceca between the groups. But, crypt depth of probiotic group $(1110.46 \pm 224.016 \mu \mathrm{m})$ was statistically deeper than that of Control Group $(949.39 \pm 114.166 \mu \mathrm{m})$ in ileum. Mucosa thickness of probiotic group in ceca and ileum appeared to be thicker than those of Control Group (Table 3). Present results are in aggreement with many other researchers who mentioned positive effects of probiotics on the gut health and accordingly growth performances (Giannanes et al., 2014; Ştef et al., 2015; Zhang et al., 2015 and Erdogmus et al., 2018). A good histological development in the ileum and ceca in the probiotic group chickens may contribute to understand the BWG and FCR efficiencies in the group compared to Control Group.

\section{CONCLUSION}

Based on the findings of the present study, it may be concluded that a continuously inclusion of a good blend of probiotics at $10^{8} \mathrm{CFU} / \mathrm{ml}$ dose in drinking water may successively improve the performance and gut health of commercial broiler chicks. Therefore, under the conditions of the present study, it can be recommended that using a freshly produced liquid microbial growth promoter in the non-medicated and de-chlorinated water could prove highly beneficial for the local broiler producers. It could be suggested that further research work should be performed to comparatively evaluate the effectiveness of freshly produced liquid live microbial cultures with other powder forms both as applications in drinking water and rations as-post pellet applications. So, replacement of AGPs with non-AGP microbial cultures, of broiler meat industry and public health safety issues could be more lessened.

\section{DECLARATIONS}

\section{Acknowledgments}

The authors appreciate the research support provided in part by Bakin Tarim Ltd, Ankara/Turkey and a grant from the Scientific and Technological Research Council of Turkey, Ankara/Turkey (Grant no. 7100168).

\section{Author`s contributions}

All authors participated equally in making the design, support with sampling andinterpretation of results, and writing the paper.

\section{Competing interests}

The authors declare that there is no conflict of interest.

\section{Consent to publish}

All persons gave their informed consent prior to their inclusion in the study.

\section{REFERENCES}

Abu-Akkada SS and Awad AM (2015). Protective effects of probiotics and prebiotics on Eimeria tenella-infected broiler chickens. Pakistan Veterinary Journal, 35(4): 446450. http://www.pvi.com.pk/pdf-files/35_4/446-450.pdf

Afsharmanesh. M and Sadaghi B (2014). Effects of dietary alternatives (probiotic, green tea powder, and Kombucha tea) as antimicrobial growth promoters on growth, ileal nutrient digestibility, blood parameters, and immune response of broiler chickens. Comparative Clinical Pathology, 23 (3): 717-724. DOI: 10.1007/s00580-0131676-x

Agboola AF, Omidiwura BRO, Odu O, Popoola IO and Iyayi EA (2015). Effects of organic acid and probiotic on performance and gut morphology in broiler chickens. South African Journal of Animal Science, 45(5): 494-501. DOI: 10.4314/sajas.v45i5.6.

Angel R, Dalloul A and Doerr J (2005). Performance of broiler chickens fed diets supplemented with a direct-fed microbial. Poultry Science, 84: 1222-1231. DOI:10.1093/ps/84.8.1222

Applegate TJ, Klose V, Steiner T, Ganner A and Schatzmayr G (2010). Probiotics and phytogenics for poultry: Myth or reality? Journal of Applied Poultry Research, 19 (2): 194 210. DOI: 10.3382/japr.2010-00168.

Blajman J, Gaziano C, Zbrun MV, Soto L, Astesana D, Berisvil A, Scharpen AR, Signorini M and Frizzo L (2015). In vitro and in vivo screening of native lactic acid bacteria toward their selection as a probiotic in broiler chickens. Research in Veterinary Science, 101: 50-56. DOI: 10.1016/j.rvsc.2015.05.017

Blankenship LC (1992). Report at international poultry exposition in Atlanta. 22-24 January. 
Callaway TR, Edrington TS, Anderson RC, Harvey RB, Genovese KJ, Kennedy CN, Venn DW and Nisbet DJ (2008). Probiotics, prebiotics and competitive exclusion for prophylaxis against bacterial disease. Animal Health Research Revievs, 9(2): 217-225. DOI: $10.1017 / \mathrm{S} 1466252308001540$.

Castanon JI, (2007). History of the use of antibiotic as growth promoters in European poultry feeds. Poultry Science, 86(11): 2466-2471. DOI:10.3382/ps.2007-00249

Chughtai SA, Khan AR, Hussain S and Iqbal S (2015). Effect of multi-strain probiotic on immune response and growth of broilers vaccinated against Newcastle disease. Pakistan Journal of Science, 67(3): 225-229. DOI: $10.1080 / 03079450802356995$

Davies DS (2013). Antibiotics, G8 Summit, ICPIC 2013. The Global Journal, Available at: http://theglobaljournal.net/photo/view/1789. Date accessed: May 6, 2016.

Eckert NH Lee JT, Hyatt D, Stevens SM, Anderson S, Anderson PN, Beltran R, Schatzmayr G, Mohnl M and Caldwell DJ (2010). Influence of probiotic administration by feed or water on growth parameters of broilers reared on medicated and nonmedicated diets. Journal of Applied Poultry Research, 19: 59-67 DOI: 10.3382/japr.200900084

Erdogmus SZ, Gulmez N, Findik A, Sah H and Gulmez M (2019). Efficacy of probiotics on health status and growth performance of Eimeria tenella infected broiler chickens. Kafkas Universitesi Veteriner Fakultesi Dergisi,25(3): 311-320.. DOI:10.9775/kvfd.2018.20889

Fuller R (1989). Probiotics in man and animals: A Review. Journal of Applied Bacteriology, 66: 365-378. http://performanceprobiotics.com/Downloads/Articles/Full er\%201989\%20Probiotics\%20in\%20man\%20and\%20anim als.pdf

Gaggia F, Di Gioia D, Baffoni L, and Biavati B (2011). The role of protective and probiotic cultures in food and feed and their impact in food safety. Trends in Food Science and Technology, $22 \quad$ (1): $\quad$ S58-S66. DOI: 10.1016/j.tifs.2011.03.003.

Getachew $\mathrm{T}$ (2016). A review on effects of probiotic supplementation in poultry performance and cholesterol levels of egg and meat. Journal of World Poultry Research, 6(1): 31-36. PII: S2322455X1600006-6.

Ghadban GS (2002). Probiotics in broiler production - a review. Archiv fur Geflugelkunde, 66(2): 49-58. https://pdfs.semanticscholar.org/b7ff/91e382aac5f726a637 3dec5343a938c48b56.pdf

Giannenas I, Tsalie E, Triantafillou E, Hessenberger S, Teichmann K, Mohnl M, and Tontis D (2014). Assessment of probiotics supplementation via feed or water on the growth performance, intestinal morphology and microflora of chickens after experimental infection with Eimeria acervulina, Eimeria maxima and Eimeria tenella. Avian Pathology, 43(3): 209-216. DOI: 10.1080/03079457.2014.899430.

Griggs JP and Jacob JP (2005). Alternatives to antibiotics for organic poultry production. Journal of Applied Poultry Research 14(4):750-756. DOI: 10.1093/japr/14.4.750.
Heres LB, Engel F, Van Knapen MCM, De Jong J, Wagenaar A and Urlings HAP (2003). Fermented liquid feed reduces susceptibility of broilers for Salmonella enteritidis. Poultry Science, 82 (4): 603-611. DOI:10.1093/ps/82.4.603

Hume ME (2011). Historic perspective: Prebiotics, probiotics, and other alternatives to antibiotics. Poultry Science, 90(11): 2663-2669. DOI: 10.3382/ps.2010-01030.

Khan S H, Sardar ARR and Khawaja T (2013). The effect of probiotic supplementation on the growth performance, blood biochemistry and immune response of reciprocal F1 crossbred (Rhode Island Red Fayoumi) cockerels. Journal Applied Animal Research, 41(4): 417-426. DOI: 10.1080/09712119.2013.792732.

Landy N and Kavyani A (2013). Effects of using a multi-strain probiotic on performance, immune responses and cecal microflora composition in broiler chickens reared under cyclic heat stress condition. Iranian Journal of Applied Animal Science, 3(4): 703-708. http://ijas.iaurasht.ac.ir/article_513433_023cbb39b337a6d ee4bac3d24e7ffb6c.pdf

Latha S, Vinothini G, John D, Calvin D, Dhanasekaran D (2016). In vitro probiotic profile based selection of indigenous actinobacterial probiont Streptomyces sp. JD9 for enhanced broiler production. Journal Bioscience and Bioengineering, 121(1): 124-131. DOI:10.1016/j.jbiosc.2015.04.019

Lee YJ, Kang MS, Woo YK, Mo IP and Tak RB (2001). Competitive exclusion against Salmonella gallinarum of Salmonella enteritidis infected chickens. Journal of Veterinary $\quad$ Science, $2(1)$ : 33-36. http://www.vetsci.org/journal/view.html?volume=2\&numb $\underline{\text { er }=1 \& \text { spage }=33}$

Li YB, Xu QQ, Yang CJ, Yang X, Lv L, Yin CH, Liu XL and H. Yan. (2014). Effects of probiotics on the growth performance and intestinal micro flora of broiler chickens. Pakistan Journal of Pharmaceutical Sciences, 27(3): 713717.https://pdfs.semanticscholar.org/44ce/00c6bdefec497e b2108589fa6f8e37ad6262.pdf

Luna LG (1968). Manual of histologic staining methods of armed forces institute of pathology. 3rd ed. pp. 222-2226. Mc Graw-Hil Book Comp, New York.

Lutful Kabir SM (2009). The Role of Probiotics in the Poultry Industry. International Journal of Molecular Sciences 10(8): 3531-3546. DOI: 10.3390/ijms10083531.

Mahdavi S, Zakeri AY, Mehmannavaz Y and Nobakht A (2013). Comparative study of probiotic, acidifier, antibiotic growth promoters and prebiotic on activity of humoral immune and performance parameters of broiler chickens. Iranian Journal of Applied Animal Science 3(2): 295-299. http://ijas.iaurasht.ac.ir/article_513986_afc8881bc1827dd9 2205b0a44987ae3e.pdf

Mehr AM, Hassanabadi A, Nassiri Moghaddam H and Kermanshahi H (2014). Supplementation of clove essential oils and probiotic on blood components, lymphoid organs and immune response in broiler chickens. Research Opinions In Animal Veterinary Science, 4(4): 218-223. http://www.roavs.com/pdf-files/Issue-4-2014/218-223.pdf

Maturin L and Peele JT (2001). Bacteriological analytical manual, Chapter 3. Aerobic Plate Count. 
https://www.fda.gov/Food/FoodScienceResearch/Laborato ryMethods/ucm063346.html

Nami YB. Haghshenas B, Abdullah N, Barzegari A, Radiah D, Rosli R and Khosroushahi AY (2015). Probiotics or antibiotics: future challenges in medicine. Journal of Medical Microbiology, 64: 137-146. DOI 10.1099/jmm.0.078923-0

MacDonald JM and Wang SL (2011). Foregoing Sub-therapeutic Antibiotics: the Impact on Broiler Grow-out Operations. Applied Economic Perspectives and Policy, 33(1): 79-98. DOI: $10.1093 /$ aepp/ppq030.

Nikpiran H, Vahdatpour T, Babazadeh D, Tabatabaei SM and Vahdatpour S (2014). Effects of Functional feed additives on growth influenced hormones and performance of japanese quails (Coturnix japonica). Greener Journal of Biological Sciences, 4 (2): 39-44. ISSN: 2276-7762. DOI: 10.15580/GJBS.2014.2.021014096. Nurmi E and Rantala M (1973). New aspects of Salmonella infection in broiler production. Nature, 241: 210-211. DOI: 10.1038/241210a0

O'Dea EE, Fasenko GM, Allison GE, Korver DR, Tannock GW, and Guan LL (2006). Investigating the effects of commercial probiotics on broiler chick quality and production efficiency. Poultry Science, 85: 1855-1863. DOI:10.1093/ps/85.10.1855

Olnood CG, Beski SSM, Iji PA and Choct M (2015). Delivery routes for probiotics: Effects on broiler performance, intestinal morphology and gut microflora. Animal Nutrition, 1(3):192-202. DOI: 10.1016/j.aninu.2015.07.002

Otutumi LK, Gois MB, Garcia ERM and Loddi MM (2012). Variations on the Efficacy of Probiotics in Poultry. Chapter 9, Probiotic in Animals.Ed: Everlon Cid Rigobelo. DOI: $10.5772 / 50058$

Prukner-Radovcic E and Grozdanic IC (2003). Competitive exclusion against Salmonella enterica subspecies enterica serovar Enteritidis infection in chicken. Veterinarski Archiv, 73(3): 141-152.

Raevuori SE, Nurmi M and Anepizooticof E (1978). An epizootic Salmonella typhimurium var. copenhagen in broiler and the use of cultured chicken intestinal flora forits control. British Poultry Science, 19: 309-314. DOI: 10.1080/00071667808416481

Ritzi MM, Abdelrahman W, Mohnl M and Dalloul RA (2014). Effects of probiotics and application methods on performance and response of broiler chickens to an Eimeria challenge. Poultry Science, 93: 2772-2778. DOI: 10.3382/ps.2014-04207

Schneitz CE Koivunen, Tuunainen P and Valaja J (2016). The effects of a competitive exclusion product and two probiotics on Salmonella colonization and nutrient digestibility in broiler chickens. Journal of Applied Poultry Research, 25(3): 396-406. DOI: 10.3382/japr/pfw025

Sharma SN Agarwal N and Verma P (2012). Probiotics: The emissaries of health from microbial world. Journal of Applied Pharmaceutical Sciences, 2(1):138-143. http://japsonline.com/admin/php/uploads/359_pdf.pdf

Ştef L, Dumitrescu G, Simiz E, Cean A, Julean C, Ştef D, Pet E, Peţ I, Gherasim V and Corcionivoschi N (2015). The effect of probiotics on broiler growth and intestinal morphology when used to prevent Campylobacter jejuni colonization.
Animal Science and Biotechnology, 48(1): 43-50. http://spasb.ro/index.php/spasb/article/view/1964/1780

Swiatkiewicz S, Arczewska-Wlosek A and Jozefiak D (2014). Feed enzymes, probiotic, or chitosan can improve the nutritional efficacy of broiler chicken diets containing a high level of distillers dried grains with solubles. Livestock Science, 163: 110-119. DOI: 10.1016/j.livsci.2014.03.001.

Tellez G, Pixley C, Wolfenden RE, Layton SL and Hargis BM (2012). Probiotics/direct fed microbials for Salmonella control in poultry. Food Research International, 45(2): 628-633. DOI: 10.1016/j.foodres.2011.03.047.

Timmerman HM, Veldman A, van den Elsen E, Rombouts FM and Beynen AC (2006). Mortality and growth performance of broilers given drinking water supplemented with chicken-specific probiotics. Poultry Science, 85 (8): 13831388. DOI: $10.1093 / \mathrm{ps} / 85.8 .1383$

Vahdatpour T and Babazadeh D (2016). The effects of kefir rich in probiotic administration on serum enzymes and performance in male japanese quails. The Journal of Animal \& Plant Sciences, 26(1): 34-39. ISSN: 1018-7081.

Vandeplas SC, Marcq C, Dauphin RD, Beckers Y, Thonart P and Thewis A (2008). Contamination of poultry flocks by the human pathogen Campylobacter spp. and strategies to reduce its prevalence at the farm level. Biotechnology Agronomy and Society and Environment, 12(3): 317-334.

Wolfenden AD, Vicente JL, Bielke LR, Pixley CM, Higgins SE, Donoghue DJ, Donoghue AM, Hargis BM and Tellez G (2007). Effect of a defined competitive exclusion culture for prophylaxis and reduction of horizontal transmission of Salmonella enteritidis in broiler chickens. International Journal of Poultry Science, 6(7): 489-492. DOI: 10.3923/ijps.2007.489.492

Zhang Y, Wang W, Chen Y, Wang Z and Cao J (2015). Effects of different concentrations of homologous probiotics on small intestinal mucosa structure of 42-day-old broilers. Agricultural Science and Technology, 16(12): 2782-2785. 